\title{
Internationalization of Neo-Nazism and Social Media: Psychosocial, Sociopolitical and Security Inquiry
}

\author{
Faruk Hadžića iD \\ a Independent researcher from Bosnia and Herzegovina
}

\begin{abstract}
This research analyses the internationalization paradigm of extremism and neo-Nazism, affecting related global events within the historical, psychosocial, sociopolitical, security, and globalized media framework; problematizing a gap between peace, violence, democratic legislation, social awareness, political agendas, participation, and hyperpersonal communication theories. The radicalization process can be initiated or encouraged by sociopolitical or sociopsychological circumstances that directly or indirectly affect the individual. There is no detailed profile of a person attentive to commit terrorism, various positions, and judgments. The capacity and participation in the sociopolitical process are questioned. The impoverishment of public life and the public sphere creates a critical potential for demagogic and ideological extremist manipulation. Democratic accountability and transparency could be submerged by far-right spin specialists who have more scope to manage information. Such an occurrence coincides with the mass society theories. Hyperpersonal communication initiated securitization, highlighting the internationalization of neo-Nazism and neo-Fascism (i.e., NorwegianBreivik and New Zealand-Tarrant). It is undeniably essential that a democratic, legal state has a monopoly on violence. The lack of decisionmakers in the political sphere who would: establish a different direction in the constitution of the community, understanding that managing the relevant weaponry and cognate laws is a regional, transnational, and trans-party issue, and the actual field of their political legitimacy; a failure for diverse global societies.
\end{abstract}

\author{
KEYWORDS \\ Neo-Nazism \\ social media \\ terrorism \\ public policy \\ security
}

\section{ARTICLE HISTORY}

Received: 17.05.2021

Revised: 14.10 .2021

Accepted: 14.10 .2021

\section{Introduction}

Violent extremism and radicalization leading to terrorism and transnational challenges are not limited to nationality, ethnicity affiliation, religion, ideology, or gender. Moreover, these unpredictable and evolving intimidations, lack of sociopolitical awareness, and inefficient state policies make it difficult to prevent and counter them. Social media has become a preferred method for right-wing extremists to spread their calls for violence and antagonistic rhetoric. Young people inadvertently become global right-wing medians within the socio-psychological forms of deceived communications. Sociologists and psychologists believe that specific characteristics characterize the personality of terrorists, but no one has yet determined a unique personality profile, i.e., listed the characteristics that guarantee that the person who possesses them will commit terrorist acts.

Furthermore, the functioning of democracy cannot explain only the analysis of political institutions; it is necessary to analyze the "micro" level social actors, citizens, and their attitudes and 
orientations towards politics and political institutions. Policy-oriented citizen activities can be of greater or lesser intensity, require more or less time and resources, be individual or collective, and have more or less success. A key component in achieving a refined response to neo-Nazism and neofascism ensures adequate social awareness and representation of all sociopolitical actors and individuals within the security sector, especially when defining policies and programs and operational roles in law enforcement. A characteristic of the post-modern world is the lack of security and the mixing and merging of different styles and genres. Besides, various media and communication theories must be criticized in the post-modern world because they view people as passive recipients of information. There were no independent media in Nazism. All mass media were under the strict control of the regime. Their task was not to objectively inform the population but instead to spread the ruling ideology and indoctrinate it. Thus, there is no risk from Stalinism in the twenty-first century but a variant of Nazism and Fascism.

This research analyses the internationalization paradigm of extremism and neo-Nazism, affecting related global events within the historical, psychosocial, sociopolitical, and security frameworks. It further explores media and social media in the globalized world and problematizes a gap between peace, violence, democratic legislation, social awareness, political agendas and participation, and hyperpersonal communication theories aiming to conceptualize security challenges and normative solutions. The study includes an in-depth literature review within the analytical and critical analysis methods.

\section{Findings and Discussion}

The world is marked by new waves of violent extremism, radicalism, and terrorism behind which there are religious, ethnic, and political reasons, and the ideologies of these groups oppose the democratic and liberal values of tolerance and multiculturalism. Radicalization is a dynamic process during which a person is brought into a state to accept violence, especially terrorists, as a possible and justified action of individuals and groups, i.e., uncompromising achievement of their goals. Violence is a phenomenon present in different epochs of development of human society, a constant of social relations; although it is immanent to man, we also meet it in the animal world. It can be defined as using coercive means and methods against someone against his will and rights or physical force against objects and material means.

The key reasons individuals and groups choose this type of violence are identified as the causes of terrorism. Since there is no generally accepted definition of terrorism, and the world powers have defined terrorism according to their preferences and current interests, in terms of causes, we remain of the opinion that as much as there is a definition of terrorism, there are different classifications of causes of terrorism: internal and external. Nevertheless, terrorism is a sociological construct, and as a phenomenon, it involves the use of violence to achieve political goals while causing fear among the target audience and the general public. One of the most exposed types of terrorism in the last few years is undoubtedly "lone wolf" terrorism. It is essential to point out that "lone wolf" refers to terrorists not part of any broader terrorist organization or cell. However, the term is used to distinguish between terrorist activities carried out by an individual actor and terrorist activities carried out by terrorist organizations. This phenomenon dates back to the nineteenth century and was just then a vital instrument of revolutionary activity.

For Europe and the world, by legal omissions, extreme right-wing organizations are recruited in the countries where they exist and what kind of content they share through social networks. Factual information about their activities online, from which terrorists like Brentton Tarrant, Breivik, and others learn, allows proactive action against terrorist intentions, not just action. On July 22, 2011, Norwegian Anders Behring Breivik (he translated his name into English as Andrew Berwick in his 
manifesto) detonated a bomb and launched a killing spree in Oslo, Norway killing 77 people wounding many more. It was the worst terrorist attack in modern Norwegian history and one of the worst in modern European history (Rayner et al., 2011). The bombing of government buildings in Oslo resulted in eight deaths, while a mass shooting at the Workers' Youth League of the Labor Party on Utøya Island resulted in the killing of 69 people, mostly teenagers, and the wounding of at least 96 others. Breivik's primary concern and Hitler's were the alleged "rapid extinction of Nordic genotypes." He cited data showing as an example the prevalence of blue eyes among EuroAmericans living in the US: 457.4 percent of those born between 1899 and 1905 compared to 33.8 percent of those born between 1936 and 1951. Blue eyes have become increasingly rare among American children, with only one in six to 16.6 percent, accounting for 49.8 million of the 300 million (22.4 percent of Euro-Americans) in the entire US population with blue eyes. Breivik's concern about intermarriage existed because of its eugenic implications: "A century ago, 80 percent of people married within their ethnic community. Blue eyes are routinely passed on, especially among people of Western and Northern European descent. About half of Americans born at the turn of the twentieth century had blue eyes, according to a 2002 study by Loyola University in Chicago. By the middle of the century, that number had dropped to a third. Today, only 1 in 6 Americans has blue eyes" (Silver, 1997).

His first political experiences concerned right-wing parties that had solid anti-immigrant platforms. As he failed to make significant progress and be recognized in political parties and circles, he turned to online extremist forums to communicate with various radicals, extremists, and likeminded people. It is where his immersion in the virtual world and social isolation from the external social environment began. The most significant role in developing ideas and creating his ideology in Breivik was played by the Internet and various available extremist literature and platforms on which he exchanged his views and ideas with others. Lonely wolves with radical right-wing motives usually stand out on such platforms because they are people who find pleasure in portraying their aggression - for example, through various virtual discussions of terrorism - and see it as an effective means of expressing their problems and desires (Hartleb, 2020). Over time, Breivik's beliefs became more radical, and his desire for action grew, but he no longer found sufficient support in the forums. The feeling of rejection reappears, but this time it was that feeling that made him go all the way and take matters into his own hands. He then began writing his manifesto, planning and preparing for the attack, with the Internet once again serving as his primary tool.

In New Zealand, Brenton Harrison Tarrant announced his mass killing over social media and filmed it live on the Internet. He shared a 74-page online manifesto peppered with sarcastic jokes about popular culture, repeating well-known internet memes and striving to mint new ones. He explained in a "Q\&A" format, as though in an interview, with asides to imagine the reactions. "I am sure the journalists will love that," he wrote, after answering "yes," to his question, "Were/are you a fascist?" "Terrorism is the propaganda of the deed, and the terrorist is always as interested in his audience as his victim," paraphrasing the nineteenth-century Russian anarchist Mikhail Bakunin. Social media makes this vector much more powerful. We become host to the virus, and we accelerate its spread. According to his father's obituary in The Daily Examiner of Grafton, the suspect's parents were divorced early in his childhood. Tarrant's mother was not mentioned in the obituary, suggest an ordinary white man from "a working-class, low-income family," Tarrant wrote in his manifesto. "I had a normal childhood, without any significant issues." "I had little interest in education during my schooling, barely achieving a passing grade. I did not attend University as I had no great interest in anything offered in the Universities to study." His manifesto alludes to visits to Poland, North Korea, Ukraine, Iceland, and Argentina. References throughout his manifesto indicate that he was deeply immersed in white nationalist internet forums. He also appears to have developed a detailed 
interest in American politics. To make his case for the effectiveness of memes, he pointed to a candidate in the 2016 Republican presidential primary he found boring: "Jeb Bush inspires no one."

"Are you a supporter of Donald Trump?" Tarrant asked himself in the manifesto. "As a symbol of renewed white identity and purpose? Sure. As a policymaker and leader? Dear God, no." He wrote that, in some ways, his attack was explicitly aimed at an American audience. "I chose firearms for the effect it would have on social discourse. The extra media coverage they would provide and affect it could have on the politics of the US and thereby the political situation of the world." He hoped "to create conflict between the two ideologies within the US on the ownership of firearms in order to further the social, cultural, political and racial divide." Thus ensuring the death of the "melting pot" pipe dream.

Sociologists and psychologists believe that specific characteristics characterize the personality of terrorists, but no one has yet determined a unique personality profile, i.e., listed the characteristics that guarantee that the person who possesses them will commit terrorist acts. Human nature is not a place where one can find answers to the emergence of neo-Nazism, neo-Fascism, and terrorism. However, it is undoubtedly unavoidable in cooperation with other social and economic problems, poverty, and alienation of certain social groups and strata (Aechtner, 2016). In the group of objective social factors that drive subjective, that is, radical attitudes and understanding of terrorism as a legitimate and only means, we can also classify several recognized by international institutions, namely: prolonged unresolved conflicts, lack of the rule of law, violation of human rights, national and religious discrimination, political exclusion, socioeconomic marginalization and lack of good governance. Feelings of victimization, injustice, frustration, humiliation, and revolt can affect the development of negative feelings and insecurity about identity and belonging, which are reflected in the individual's reaction to society. Social interactions, interpersonal relationships, and exposure to ideas and messages that legitimize terrorism, in conjunction with psychological and cognitive factors, lead the individual to terrorist radicalization (OSCE, 2014). Adolescents and young people in their early twenties are considered the most vulnerable category for mobilizing and embarking on the path of radicalization and violent extremism, but that does not necessarily mean that they will all accept neo-Nazi and neo-Fascist ideologies as a legitimate means and end up on the tracks of terrorist acts. Every criminal behavior is caused by a combination of two groups of factors: personal traits of an individual and external (primarily social) factors, where their action does not have the same force in all crimes, because, in some, it is dominated by the individual, in others external factors, while in others it is united, the action of individual and external factors. Violence is most often reacted to with violence, which can be one of the potential causes of radicalization in certain societies.

As for Breivik's psychological condition, from the analysis of his actions, it could be concluded that he is a rational person because otherwise, he would not be able to carry out an enterprise of such catastrophic proportions. In addition, 1,500 pages of his manifesto also show his particular intellectual abilities. However, a subsequent police psychological assessment concluded that Breivik had developed a mental disorder of paranoid schizophrenia during his lifetime that changed him and turned him into today's person. They deduced this from Anders' misconceptions, according to which he believed it was up to him to determine who should live and who should die (Pantucci, 2011). It is believed that Breivik started showing signs of certain psychological disorders in 2006 when he moved in with his mother and became socially isolated. His mother told the court that in 2011 when he was still living with her, he started wearing an antiseptic mask around the house, refused to eat the food she prepared for him and kept calling the family doctor and accusing her of infecting him with some disease (Pantucci, 2011). Also, according to Pantucci's analysis, Breivik showed a high level of narcissism, as can be seen from several examples. The first example is the plastic surgery of the nose to which he underwent to, in his opinion, look more like the Aryan race. Then, through texts in the manifesto, he repeatedly mentions himself in the context of his "good appearance and charm," by 
which he can very easily win girls over. Breivik's interview with himself presented in the manifesto, with the help of which he is rehearsing for potential future interviews, which he hopes will follow after the attack, is another piece of evidence for this claim.

The functioning of democracy cannot explain only the analysis of political institutions; it is necessary to analyze the "micro" level social actors, citizens, and their attitudes and orientations towards politics and political institutions. Policy-oriented citizen activities can be of greater or lesser intensity, require more or less time and resources, be individual or collective, and have more or less success. Fox (2013), in detail, describes the different criteria for the conceptualization of political participation. Is political participation active or passive, whether it must be a matter of visible behavior or political attitudes and values as well "Latent" dimensions of the political party participation? Does political participation refer to individual behavior or group engagement? Must it be an instrumental activity and have clearly defined goals and outcomes? Either symbolic activities without clearly defined requirements or goals, so where do they count? The criterion can also be the legality of the action, motivation, outcome, and the goal of the action (Fox, 2013). Digital technologies further complicate the criteria for defining participation. At the same time, global democracy can also be seen as a substitute for the short-lived concept of the "new world order". The threat to democracy comes precisely from the sphere of the legitimacy of the democratic choice of a populist authoritarian regime (leader), which, based on this "democratic electoral legitimacy," is authorized to make further political and economic changes without any public oversight. The populist regime (leader) derives from that "democratic electoral legitimacy," the legitimacy right to abolish any possibility of public criticism that usually qualifies as political resistance of the opposition.

Alternatively, as hostile provocations of the "fifth column" or as a conspiracy of national or religious minorities or migrant groups, which creates a climate of fear, mistrust, and repression, new perspectives open up for authoritarian regimes whose hands all political power is concentrated. However, Western European societies' history can also be read as a sequence of dominant lines of conflict, starting from the contradictions of Catholicism and Protestantism, the periphery and the center, the agrarian economy and industry. When the lines of conflict lose clarity, the old antagonisms do not disappear completely. They still exist and are reflected in party systems (Hadžić, 2020). Pim Fortuyn was a Dutch politician, academic, sociologist, and Pim Fortuyn List's political party. In 2001, he appeared on the political scene in the Netherlands, intending to become the new prime minister. His political rise took place in a turbulent and polarized climate. He made various bold statements about Islam, a multicultural society, immigration policy, asylum policy, and his political opponents. For example, he wanted to limit the number of immigrants in the country, arguing for a Cold War against Islam because Islam posed a severe threat to Dutch society - he considered mosques to be "leading organizations in which martyrs are raised" and Islam a "retarded culture" (Van Buuren, 2013). His statement also circulated in the media, claiming that the entire environmental policy in the Netherlands no longer makes sense and that he is tired of their environmental movement (Posluszna, 2015).

According to the pessimistic view of the reality and future of audience democracy, the quality and ability to overcome conflict and solve problems will decline in absolute terms and compared to the worst performance of party democracy. Pessimists point to a state collapse scenario that repeats the history of fragile bourgeois governments in Germany and Italy since 1918. and the history of overburdened progressive governments in the West since the oil crisis of the 1970s. According to this view, the state will crash for several reasons: (1) stagnation and failure of public policies as a result of inadequate managerial skills of campaign politicians; (2) demands of poorly informed citizens for immediate satisfaction by transparent policymakers; (3) excessive influence of media owners and journalists on the agenda and success of parties, parliaments; (4) obsessions of political leaders and managers in the public sector with daily political support and short-term public interests; (5) 
unnecessary continuation or introduction of wrong communication designs, programs, and projects of the state (Dahl, 2006). According to this view, examples of failures are domestic terrorism encouraged by immigrants, the declining competitiveness of European capitalism, the unsustainability of the pension system, and the occupation of Iraq. Nonetheless, Western audience democracies thrive in societies that continue to lead or are at least satisfactory in the capacity of the state (subsystems of taxation and aid to the poor), the moral integrity of officials, the peaceful resolution of conflicts, and legislative reforms, which is expressed through economic growth, competitiveness, creativity, human development, economic freedoms, and happiness.

The Nazis in Germany under Hitler largely solved the unemployment problem and stabilized the German mark, resulting in mass support for the regime. That is, National Socialism thus gained "passive tolerance of the masses." Social security was his only truth-based propaganda slogan (Neumann, 2012). The masses were gained by propaganda. The natural structure of society has been replaced by an abstract "people's community" that "conceals the depersonalization of human relations" and the isolation of man from man. In the categories of modern social psychology, it can be said that National Socialism intended to create a uniform sadomasochistic character. Alternatively, the type of man determined by his isolation and insignificance is driven by this fact into a collective body where he acquires a share in power and celebrates the entity he is a part of (Neumann, 2012). The most effective means of Nazi propaganda was radio. The German population was allowed to listen exclusively to German radio stations. Listening to other stations, such as the British BBC, was severely punished. After the Nazis came to power, they fostered the myth of a leader (Führer) who supposedly embodied the historical mission of the German people, and therefore, the party and the people must unconditionally follow. The Führer "comes out" of the people and is in a "close relationship" with them. The leader is at the center of the movement; he is irreplaceable. In his person, he unites the fourfold function of the head of state, the head of the administrative apparatus, the legislator, and the supreme judge. He also has the constitutional power and is the army commander (Prelot, 2002). Italian Fascism (1922-1943) is also a regime in which the leader (Duce) is at the system's center. On the continuum of political regimes, limited by the poles of "ideal democracy" and "complete totalitarianism," National Socialists ranks "farthest at the totalitarian end." In Italy, it remained through the power centers (the king, the army that remained loyal to the king, the church) that were "never completely subordinated" to the fascist regime.

The Nazis advocate the establishment of a community. Community is understood as a race, a unity that is guaranteed by "blood and soil." The people, on the other hand, are understood as a "natural-organic" unity and wholeness. It exists before any differentiation of society into classes, interest groups. On the other hand, the Communists advocate establishing such a community with no oppression and exploitation. Of course, a classless society that seeks to establish itself, at least at the level of ideology, re-actualizes the "ancient" myth of the "golden age" (Bruneteau, 2010). Over time, after the period, the so-called. The dictatorships of the proletariat will be overcome by the foremost oppressive institution - the state, which the association of free producers will replace, at the level of ideology, the equality of community members in the so-called post-revolutionary period except those who are members of the exploitative bourgeois class.

In a study by the International Research Center for Combating Terrorism (ICCT) in The Hague, the causes of radicalization that can lead to terrorism are on three levels. The first is the individual's level, which includes an identity crisis, feelings of alienation, marginalization, discrimination, stigmatization, and rejection in (often) combined with anger and revenge. The second level represents the wider radicalized community that supports terrorism, or it can even be a group that operates in secret and is a link ("missing") on the way to a terrorist organization. It most often happens within a social group exposed to difficult living conditions, which can be a fertile ground for radicalization. National, ethnic or religious groups that are a minority in a particular state are vulnerable. The third 
or macro level refers to the role of government and society in the country and abroad, the radical attitudes of public figures and politicians, especially those who come from abroad. In addition, the lack of opportunities for a decent socioeconomic status can lead to mobilization and radicalization, which can eventually manifest itself through terrorist acts (Schmidt, 2013). The first-level approach is still dominant in research into the radicalization process.

Austria has already taken steps to detect extremist movements and recently opened an investigation against the extreme right-wing Identity Movement led by Martin Sellner, which was also linked to Christchurch's terrorist attack. After the terrorist attack on two mosques and the deaths of dozens of innocent people, New Zealand's state and society realized that the culture of death threatened their "multiculturalism," and with determination, they tackled the challenges. In addition to strengthening the inclusive cultural pattern through education, media, and other platforms, the country, immediately after the March tragedy, began passing a law banning the possession of military weapons, which was adopted in the New Zealand Parliament. In Germany, a law that will force social networks to delete posts containing hate speech and fake news came into force in 2018. Under it, if it is clear hate speech, the penalty for not removing the content is up to 50 million euros. At the same time, the sites have 24 hours after being notified that the content is illegal to take action. Twitter has started adhering to this law, so the Alternative for Germany (AfD) MP Beatrix Storch, whose account was banned at noon, was deleted. Before the law went into effect, Facebook banned 10,000 profiles in Germany in August for spreading fake news and misinformation (DW, 2018).

\section{Media and social media in the globalized world}

The rise of the media and cultural industries, as well as the information society, coincided with, in Barnett's words, an "all-pervading feeling of declining cultural, educational and political standards" or "dumbing down" (Barnett, 1998). There were no independent media in Nazism. All mass media were under the strict control of the regime. Their task was not to inform the population objectively but to spread the ruling ideology and indoctrinate the population. Thus, there is no risk from Stalinism in the twenty-first century but a variant of Nazism and Fascism. The crisis of modern societies creates fertile ground for the establishment of such regimes. Various techniques have proven effective in spreading ideologies, and transferring the work of PR professionals to influencers has proved expedient as it has been shown that, due to the human voice and home atmosphere, consumers do not always question the credibility and sincerity of these sources. Media and social networks have penetrated various sociopolitical spheres and made possible the spread of ideological constructs, including misinformation, virtual abuse, false identification, goal setting, and hybrid warfare. Moreover, we also lack detailed empirical data about the online lives of modern terrorists.

There are two inclinations. First, Neo-Nazis are increasingly hiding their right-wing extremist messages behind the facade of pop culture. Second, at the same time, they avoid inappropriate slogans and instead play the card of trendy presentations with colorful colors and well-known positive characters. Thus, for example, the plush figure of Cookie Monster from Sesame Street is used to spread right-wing slogans. Elsewhere in the network, a plush figure "Deportomedo" (AbschiebBär) is used to distribute neo-Nazi content. Alternatively, so the character of Micky Mouse with the SS corpse head became a cult neo-Nazi figure through numerous sharing and "liking" online. With the help of deceived communications, young people inadvertently become right-wing medians globally. At first glance, the web links do not seem to lead to something unusual because (i.e., the Facebook page of a young man as a Youtube video is the title of a recent Hollywood movie). However, behind the announcement of the film "Pirates of the Caribbean 5" extends something completely different, instead of Hollywood - incitement. The neo-Nazi group "Immortals" thus spreads its inflammatory messages. Moreover, the user often discovers the right-wing extremist 
background of the message too late. Usually, this status already has "likes" at that time and is shared further (Fuchs and Martinovic, 2014).

Giddens (2009) attempts to simplify the ideas of the French philosopher Jean Baudrillard and says that there was a time when it was possible to separate the natural world and its events from the media-represented world. He explains that Baudrillard's theory speaks of the demolition of that boundary because media representation has become part of that hyperrealistic world and can no longer be viewed in isolation from it. Various media and communication theories must be criticized in the post-modern world because they view people as passive recipients of information. The process of determining globalization of media is influenced by the understanding and infrastructure (information and communication technology) on which the network is based (Boyd and Ellison, 2007) and thus build mass communication that uses the mass media. The new media have joined the traditional media, and their most essential characteristics are data processing in digital form, multimedia, prompt interactivity, hyper-textuality, and the creation of an increasingly virtual world. Today, social networks are increasingly entering that system. The popularity of networks is growing, and usage habits are changing dynamically (hours spent on communication and information exchange), with an increasing focus on photography and less on texts and creativity. The choice of networks is expanding (YouTube, Instagram, Facebook, Twitter, Pinterest, Tumble, LinkedIn) and the use of applications such as Messenger, WhatsApp, Skype, Viber, Snapchat.

The example given by Pantucci (2011), which demonstrates the high level of Breivik's selfobsession, are the photographs, Breivik, himself published at the end of his manifesto, which present him to the general public and the world. The case of the Norwegian far-right terrorist Anders Behring Breivik offers unique insights into the online activities of a terrorist who used the Internet and social media in almost every thinkable way. Not only did Breivik compile his 1516-pages long compendium based exclusively on Internet sources. Before the attacks, he was also an active discussant on many mainstream and extremist Internet forums and a highly dedicated online gaming enthusiast. Breivik's online posts indicate that his critical views on Islam and socialism were established long before counterjihad blogs were created. It means that these blogs may have played a less decisive role in Breivik's early radicalization than assumed by many. Later on, however, these blogs strengthened Breivik's radical thinking, although they come across as far less radical than his ideological statements after July 22 (Ravndal, 2013). Tarrant opened his video of his killing by reciting the slogan of the preteen and adolescent fans of a wildly popular YouTube channel devoted mainly to humor and video games (although also sometimes touched by accusations of anti-Semitism or anti-Muslim bigotry): "Remember, lads, subscribe to PewDiePie." "Were you taught violence and extremism by video games, music, literature, cinema?" Tarrant asked himself, answering with sarcasm: "Yes. Spyro the Dragon 3 taught me ethnonationalism. Fortnite trained me to be a killer and to floss on the corpses of my enemies." "Paint, write, sing, dance, recite poetry. Hell, even meme," Tarrant wrote. "Memes have done more for the ethnonationalism movement than any manifesto." He later recommended "edgy humor and memes" and appealing "to the present's anger and black comedic nature." By his own account, he was radicalized during one-month travels in Europe in spring 2017. Tarrant is not the first killer to take a cue from social media or relish its reaction. In 2015, a gunman in Roanoke, Va., sought to stream a video of his killing of two local television journalists. A gunman attacking an Orlando, Florida nightclub paused between shots to post on his own Facebook page the following year. Mass murderers often seek to innovate to outdo their predecessors, including through the exploitation of the media. Tarrant appears to have broken new ground in his self-conscious efforts to surf the waves of internet fandom (Kirkpatrick, 2019).

Social media has enabled interaction and more precise information, and personal communication itself could cause human frivolity during presidential elections and other situations. Terrorism as a spectacle suppressed other spectacles after 9/11. Current "negative destruction" has 
been a defining feature of capitalist modernity from the very beginning. Life itself has become like a movie. Despite the "information blizzard," the number of sources of information is decreasing due to media consolidation and rigid corporate control. In the late 1960s, the emphasis was on "postmaterialist" values and civil rights. The concepts of individualism are becoming more complex about movements for gender, racial and ethnic emancipation. Concerns about the planet's fate are growing, and global media are consolidating interest in global civil society and citizenship. The phase of antagonism begins in the late 1990s. The key actors are World Trade Organization, USA, Kyoto Protocol, global media, anti-globalization movements and demonstrations, fundamentalist movements, regional conflicts and genocides, terrorism, wars in which Western powers participate but are not fought in their territories. This period is characterized by: globalization, capitalism, fundamentalism, nationalism, multiplied identities, cosmopolitanism, anti-globalization, human rights. Given that there is no detailed information about the media and communication from the past, was globalization before 1875, Rantanen (2004) asked. It is the argument that is most often made against globalization.

Even the classic questions about the relationship between the media and society, the social role of the media, and the like are always re-actualized after establishing new political, economic, social, and cultural contexts and power relations. At the same time, the so-called transitional historical epochs are exciting historical moments that provide an opportunity to gain insight into the paradigmatic changes that have occurred in the models, functioning, role, and operation of media institutions in the broader social context. The historical moment, which is still often labeled postsocialist, thus marking only the first stage in the transition from a centralist, state-party regulated economy to a deregulated market-economic capitalist structure of society, has inevitable consequences in the context of media institutions. Moreover, pluralism and diversity of media content, the concentration of ownership in the domain of media, media legislation and regulations, and the image and opportunities of media audiences, mentioned transitional, sociopolitical and economic reorganization brings one background, but a key, side of this model. It is a complex heterogeneous but recognizable form of transforming society into a market, a citizen into a consumer, a public into a private, an information-educational into a commercial. Considering the arguments of certain media theorists, such as Baudrillard, technology, i.e., the medium, is not entirely neutral towards the user because its structure more or less directs its behavior. Thus, according to Castells, information and communication technology development created an environment for a new communication phenomenon called mass self-communication. Massive includes a potentially global audience, while the term "self-communication" means self-generated, self-disseminated, and selfselected content (Castells, 2015). Today, social media is one of the main factors in a person's everyday life, both private and professional. Social platforms influence interpersonal interaction at the individual and public levels.

Furthermore, digital technologies and social media further complicate the criteria for defining political participation. Is it online that digital participation is a legitimate and separate form of political action, or will it intertwine with other forms of participation and not be viewed as a separate form? We can problematize whether intentional abstinence from voting should be included in the repertoire of political participation since dissatisfaction is thus expressed political system.

The influence of social media is also present on a more comprehensive social level, which affects the increasingly strong identification of online and offline environments, which gives them both technological and social character. Blogs were created in the late 1990s, and social networks have been around since 1995. The latter shows that social media is not a new phenomenon in technological terms. However, their relatively newfound popularity is mainly due to the growing investment of corporate capital and the recognition of the role and influence of social media as marketing platforms (Fuchs, 2013). Features of social media (networking, participation, constant and continuous self- 
communication, and interaction, user-generated content, broad emotional experience, and experience) are today integrated into many different platforms and traditional media to make them more sociable and thus more attractive to both end-users and those across the spectrum where social media marketing opportunities create added value to the overall business. Although large companies are significant investors in social media, their interest is based on user data rather than the public and open character of the web. From the perspective of traditional liberalism, entertainment on social media is problematic because it is not a continuation of rational-critical debate or the flow of information between the government and those governed, except in a dishonest way. Liberal commentators are, as Curran points out, responded to this dilemma in three ways: (1) some criticized the growth of media entertainment as a deplorable departure from the critical democratic purpose and function of the media; (2) others ignored the existence of entertainment; (3) the third answer was the discussion of media entertainment as a particular category that is not related to the political role of the media, defining the liberal position that entertainment is a form that maximizes people's satisfaction (Curran, 1991). However, the Radicals believe that entertainment should be seen as consumer satisfaction and enable better self-expression in relationships.

The media strongly influence social behaviors, the formation, and transmission of values, the shaping of lifestyles, attitudes, and identities. The almost unlimited availability of media content through numerous social networks and new platforms makes the media ubiquitous in everyday life. It justifies critical reviews of specific media content in which violent behavior, materialism, prejudices, stereotypes are transmitted as desirable values. Young people use the media to identify adolescent culture, learn how to deal with certain life circumstances, and build their own identities. Therefore, the ability to critically evaluate media messages is one of the critical skills for developing attitudes among young people in today's media-mediated world. Physiological reactions are rapid pulse and breathing. Such arousal temporarily increases the possibility of aggressive thoughts, feelings, and behavioral scenarios, increasing the likelihood that a person will react aggressively. Also, exposure to media violence alone will not turn someone into a violent person should not be left out, but other factors are required.

\section{Conclusion}

The main challenge in preventing radicalization and the emergence of violent extremism is understanding the causes of their emergence, i.e., the drivers of radical and even extremist behavior. There is no detailed profile of a person attentive to committing extreme violence. Instead, people convert to terrorism individually, with various positions and judgments. The radicalization process can be initiated or encouraged by sociopolitical or socio-psychological circumstances that directly or indirectly affect the individual. Individuals join radicalized groups, and the reasons why such groups were formed are complex, different, and, above all, of a local character. Although more and more information is available, public incomprehension is growing, while sensationalist, vulgar, nationalist, and manipulative narratives could be incited. It poses a threat to global democracy. The capacity and participation in the sociopolitical process are questioned. The impoverishment of public life and the public sphere creates a critical potential for demagogic and ideological extremist manipulation.

A society-wide approach is needed to prevent and counteract extremism. It reflects an understanding that efforts in the fight against terrorism and violent extremism can no longer be the responsibility of security actors alone. For practical goals, a cooperative and inclusive approach to prevention is needed to oppose radicalism, including other government bodies such as civil society actors. It also means that trust must be improved and communication between security actors and communities. Democratic accountability and transparency could be submerged by far-right spin specialists who have more scope to manage information. Such an occurrence coincides with the mass 
society theories. Hyperpersonal communication initiated securitization, highlighting the internationalization of neo-Nazism and neo-Fascism (i.e., Norwegian-Breivik and New ZealandTarrant). It is undeniably essential that a democratic, legal state has a monopoly on violence. A monopoly on violence by such a state is the only monopoly that can be argued. Thus, with the fulfillment of other conditions, a peaceful society can be created. Extremism and violence is crucial obstacle to a better life for the civic masses. The lack of decision-makers in the political sphere who would: establish a different direction in the constitution of the community, understanding that managing the relevant weaponry and cognate laws is a regional, transnational, and trans-party issue, and the actual field of their political legitimacy; a failure for diverse global societies.

\section{Disclosure Statement}

The author reported no potential conflict of interest.

\section{Notes on Contributor}

Faruk Hadžić is an Independent researcher and an author from Bosnia and Herzegovina. His academic background and research are multidisciplinary in Social and Political Psychology, Political Science and International Relations, Critical Security Studies, Sociology and Socioeconomics, Criminal Justice, Ethics, Sociology of Religion, and Media Studies.

\section{ORCID}

Faruk Hadžić iD https://orcid.org/0000-0003-1158-7858

\section{Bibliography}

Aechtner, T. (2016). Terrorism in the Evolution Wars: Mass Media and Human Nature. Theology and Science, 14(4), 495517

Barnett, S. (1998). Dumbing Down or Reaching Out: Is It Tabloidisation wot done it? in: Politics and the Media: Harlots and Prerogatives at the Turn of the Millennium. Seaton, Abingdon: Blackwell.

Bruneteau, B. (2010), Le totalitarisme- Origines d'un concept, genèse d'un débat 1930-1942 (DEMOCRATIE TOTALITARISME). France: CERF Publisher.

Boyd, D. and Ellison, N. (2007). Social Network Sites: Definition, History and Scholarship. Journal of Computer-Mediated Communication 13(1), 211.

Castells, M. (2015). Networks of outrage and hope: social movements in the internet age. Cambridge: Polity Press,

Curran, J. (1991). Rethinking the media as a public sphere, in: Communication and Gitizenship: Journalism and the Public Sphere, Dahlgren, Peter and Sparks, Colin (eds.), London \& New York: Routledge.

Giddens, A. (2009). Sociology, 6th edition, Cambridge: Polity Press.

Dahl, R. (2006). On Political Equality, New Haven: Yale University Press.

DW, Detsche Welle, “Top lista: FAKE NEWS 2018”, https:/ / www.dw.com/bs/top-lista-fake-news-2018/a-46801551

Fox, S. (2013). Is it Time to Update the Definition of Political Participation? (book review Whiteley, P. (2012) Political

Participation in Britain: The Decline and Revival of Civic Culture, Basingstoke: Palgrave Macmillan),

Parliamentary Affairs, 1-11, https:/ / bura.brunel.ac.uk/bitstream/2438/19098/1/FullText.pdf

Fuchs, C. (2013). Social Media: A Critical Introduction, California: Sage Publishing.

Fuchs, R. and Martinovic M. (2014). DW, “Suptilni neonacistički govor mržnje na Internetu” https://www.dw.com/bs/suptilni-neonacisti\%C4\%8Dki-govor-mr\%C5\%BEnje-na-internetu/a-17849491

Hadžić, F. (2020). The global context of authoritarian populism as democratic pylon to Fascism, and a tutorial from the Balkans, Journal of Scientific Papers “Social Development and Security," 10(6), 67-77 10.33445/sds.2020.10.6.7

Kirkpatrick, D. (2019). New York Times, https://www.nytimes.com/2019/03/15/world/asia/new-zealand-shootingbrenton-tarrant.html, 2019

Neumann, F. (2012). Behemot. Struktura i praksa nacionalsocijalizma 1933-1945. Zagreb: Disput. 


\section{Hadžıć}

OSCE. (2014). Preventing Terrorism and Countering Violent Extremism and Radicalization that Lead to Terrorism: A Community-Policing Approach. http://www.osce.org/atu/111438?download=true

Pantucci, R. (2011). What have we learned about Lone Wolves from Anders Behring Breivik? Perspectives on Terrorism, 5 (6), $27-42$.

Posluszna, E. (2015). Lone Wolves Strategy: The Case of Volkert van der Graaf and Theodore Kaczynski “, in Environmental and Animal Rights Extremism, Terrorism, and National Security, Oxford: ButterworthHeinemann.

Prelot, M. (2002). Političke institucije, Zagreb: Politička kultura.

Rantanen, T. (2004). The Media and Globalization, London: Sage Publications.

Ravndal, J. (2013). Anders Behring Breivik's use of the Internet and social media, Journal ExitDeutschland. Zeitschrift für Deradikalisierung und demokratische Kultur. https://journals.sfu.ca/jed/index.php/jex/article/view/28

Rayner, G., Gardham, D. and Bingham, J. (2011). The Telegraph, Hunt for Britons linked to Norway killer Anders Behing Breivik.

Schmid, A. (2013). Radicalization, De-Radicalisation, Counter-Radicalisation: A Conceptual Discussion and Literature Review, International Centre for Counter-Terrorism (ICCT) - The Hague

Silver, L. (1997). Remaking Eden: Cloning and Beyond in a Brave New World. New York: Avon Books.

Van Buuren, J. (2013). Holland's own Kennedy Affair. Conspiracy Theories on the Murder of Pim Fortuyn, Historical Social Research, 38 (1), 257-285. 